\title{
Institutional context and the allocation of entrepreneurial effort
}

\author{
Harry P Bowen ${ }^{1}$ and \\ Dirk De Clercq ${ }^{2}$
}

${ }^{1}$ McColl School of Business, Queens University of Charlotte, Charlotte, USA; ${ }^{2}$ Brock University, St Catharines, Ontario, Canada
Journal of International Business Studies (2008) 39, 768.

doi: 10.1 057/palgrave.jibs.8400382

Correction to: Journal of International Business Studies (2007) advance online publication 20 December, doi:10.1057/Palgrave. jibs. 8400383

The following statement in paragraph seven of the "Results" section:

Specifically, the likelihood that entrepreneurial effort will be allocated toward high-growth activities is higher the greater the extent of a country's financial capital targeted at entrepreneurship (Hypothesis 1), the greater the extent of a country's educational capital targeted at entrepreneurship (Hypothesis 2), and the greater the extent of a country's regulatory protection.

should read:

Specifically, the likelihood that entrepreneurial effort will be allocated toward high-growth activities is higher the greater the extent of a country's financial capital targeted at entrepreneurship (Hypothesis 1), the greater the extent of a country's educational capital targeted at entrepreneurship (Hypothesis 2), and the smaller the extent of corruption among a country's economic actors (Hypothesis 4).

The authors of the above article are grateful to the JIBS Editor-inChief for highlighting this error. 